\title{
Chromosomal Heterochromatin Differentiation in North American Cyprinid Fishes*
}

\author{
J. R. Gold ${ }^{1}$, C. T. Amemiya ${ }^{1}$ and J. R. Ellison ${ }^{2}$ \\ Departments of ${ }^{1}$ Wildlife and Fisheries Sciences and \\ ${ }^{2}$ Biochemistry and Biophysics, Texas A and M University, \\ College Station, Texas 77843, U.S.A.
}

Accepted March 6, 1985

With the advent of chromosomal C-banding methodology (Arrighi and Hsu 1971, Yunis et al. 1971), constitutive heterochromatin differentiation on mitotic chromosomes of many animal and plant species has become fairly routine. Among animals, most of the comparative data are from higher vertebrates, chiefly mammals. This is due primarily to the superior methods of chromosome harvest available in these species (e.g., Lee and Elder 1980). Collectively, the vertebrate data have shown that variation in both heterochromatin amount and chromosomal position is or can be extensive both within and across phyletic groups (Árnason 1974, Yosida 1975, Mascarello and Mazrimas 1977, Pathak and Wurster-Hill 1977, Schmid 1978a, b, Mengden 1981, Haiduk et al. 1981, Baverstock et al. 1982, Patton and Sherwood 1982). Most species invariably possess C-bands at or around the centromeres (procentric), and frequently at the chromosome tips (telomeric). C-bands may also be found along chromosome arms (interstitial) and as entirely heterochromatic short arms of acrocentric (submetacentric or subtelocentric) chromosomes. The variation in such "short-arm" heterochromatin is particularly impressive in the rodent genera Peromyscus and Onychomys (Robbins and Baker 1981, Baker and Barnett 1981). The function(s) of constitutive heterochromatin are essentially unknown although several hypotheses have been forwarded, some of which are supported by empirical data (John and Miklos 1979). Because many if not most species appear to differ trenchantly in C-band amount and/or chromosomal distribution, one longheld hypothesis is that heterochromatin may function as a chromosomal reproductive isolation mechanism and hence in part underlie new species formation (Yunis and Yasmineh 1971, Hatch et al. 1976, Fry and Salser 1977).

Heterochromatin differentiation on the chromosomes of fish has lagged far behind studies in almost all other vertebrates, primarily for reasons which relate to the general difficulty in working with fish chromosomes (Gold 1979a). C-banded karyotypes are published for less than thirty fish species from several widely separated groups (Table 1). Briefly, most species possess relatively small amounts of heterochromatin, most of which is procentric. About one-fourth of the species possess no heterochromatin other than procentric, but with few exceptions the rest generally possess only one or two (haploid) C-bands. Four species, three in the salmonid genus Salvelinus and one in the gobiid genus Gobius, possess a considerable number of telomeric and other $\mathrm{C}$-bands, and by far have the highest relative heterochromatin

* $\mathrm{X}$ in the series "Cytogenetic studies in North American minnows (Cyprinidae)." 
contents of the fishes thus far examined. The finding that heterochromatin amounts and variation in fish are generally small is somewhat surprising in view of the evolutionary heterogeneity of the group as a whole.

Table 1. Heterochromatin location and relative amount in various fish genomes

\begin{tabular}{|c|c|c|c|c|}
\hline Species & Family & $\begin{array}{l}\text { Hetero- } \\
\text { chromatin } \\
\text { location* }\end{array}$ & $\begin{array}{c}\text { Hetero- } \\
\text { chromatin } \\
\text { amount } \\
\text { (relative) }\end{array}$ & Reference \\
\hline Anguilla anguilla & Anguillidae & $1,3,4$ & Small & Wiberg (1983) \\
\hline A. rostrata & $" \prime$ & $1,3,4$ & $"$ & Park and Grimm (1981) \\
\hline Apteronotus albifrons & Apteronotidae & 1,3 & $"$ & $\begin{array}{l}\text { Almeida Toledo et al. } \\
\text { (1981) }\end{array}$ \\
\hline Salvelinus fontinalis & Salmonidae & 1,3 & Moderate & Ueda and Ojima (1983) \\
\hline S. leucomaenis & " & 1,2 & Large & $\begin{array}{l}\text { Abe and Muramoto } \\
\text { (1974) }\end{array}$ \\
\hline S. malma & $" \prime$ & 1,2 & $"$ & $"$ \\
\hline S. namaycush & $" \prime$ & $1,2,3$ & $\prime \prime$ & $\begin{array}{l}\text { Phillips and Zajicek } \\
\text { (1982) }\end{array}$ \\
\hline Salmo gairdneri & $"$ & 1,4 & Small & Thorgaard (1976) \\
\hline S. trutta & $"$ & $1,3,4$ & " & $\begin{array}{l}\text { Zenzes and Voiculescu } \\
\text { (1975) }\end{array}$ \\
\hline Umbra limi & Umbridae & 1,2 & " & $\begin{array}{l}\text { Kligerman and Bloom } \\
\text { (1977) }\end{array}$ \\
\hline Carassius auratus $^{\dagger}$ & Cyprinidae & 1,4 & $"$ & Ueda and Ojima (1978) \\
\hline Cyprinus carpio & , & 1 & $"$ & Ojima and Ueda (1978) \\
\hline Notropis lutrensis & $" r$ & $1,2,3,4$ & Large & This paper \\
\hline N. venustus & $"$ & $1,2,3,4$ & $"$ & $"$ \\
\hline Oryzias celebensis & Oryziatidae & $1,3,4$ & Small & Uwa et al. (1981) \\
\hline O. curvinotus & $"$ & 1,3 & " & Uwa et al. (1982) \\
\hline O. latipes & $"$ & 1 & $"$ & Uwa and Ojima (1981) \\
\hline Fundulus heteroclitus & Cyprinodontidae & 1,4 & $"$ & Kornfield (1981) \\
\hline F. parvipinnis & $"$ & 1 & $"$ & $"$ \\
\hline Poecilia sphenops & Poeciliidae & 1,2 & " & Haaf and Schmid (1984) \\
\hline Haemulon sciurus & Haemulidae & 1 & $" \prime$ & Gregory et al. (1980) \\
\hline Archosargus probatocephalus & Sparidae & 1,4 & Moderate & " \\
\hline Bairdiella chrysoura & Sciaenidae & 1,3 & Small & $"$ \\
\hline Sarotherodon aurea & Cichlidae & 1,4 & $" \prime$ & Kornfield et al. (1979) \\
\hline S. galilaeus & $" \prime$ & 1,4 & " & $"$ \\
\hline Tilapia zillii & $"$ & 1,4 & $"$ & $"$ \\
\hline Gobius fallax & Gobiidae & $1,2,3$ & Large & Thode et al. (1983) \\
\hline
\end{tabular}

* $1=$ procentric; $2=$ telomeric; $3=$ interstitial; and $4=$ short-arm (see text for details).

+ Includes 5-6 subspecies of C. auratus.

In this paper, we report the chromosomal heterochromatin distributions and amount in two closely related species of North American cyprinid fish. The study is part of our long term efforts to determine whether chromosomal mechanisms have contributed to the extensive and rapid speciation which characterizes North American Cyprinidae (Gold 1980, Gold et al. 1978, 1981), and to assess the cytotaxonomy of the species (Gold 1984). Herein we show that the two species examined possess an appreciable heterochromatic fraction in their genomes and also differ from one 
another in both heterochromatin amount and chromosomal distribution. Implications of these results are discussed in terms of chromosomal evolution and cytotaxonomy in these fishes.

\section{Materials and methods}

The two cyprinids examined in the study were collected by seining from the following localities in Texas: Notropis lutrensis (Little Brazos River, Brazos County) and Notropis venustus (Bull Creek, Travis County). Specimens were returned live to College Station and maintained in well-aerated aquaria until karyotyped. Chromosome preparations were made from either fibroblast cultures as described by Amemiya et al. (1984) or directly from kidney tissue of colcemid-injected specimens as described by Gold (1984). Slides prepared by either method were stored desiccated at room temperature for three or more days prior to C-banding.

Heterochromatin differentiation or C-banding was carried out following standard methods. Briefly, slides (chromosomes) were hydrolysed $15-20$ min in $0.2 \mathrm{~N}$ $\mathrm{HCl}$ at $37^{\circ} \mathrm{C}$, denatured in a saturated $\mathrm{Ba}(\mathrm{OH})_{2}$ solution at room temperature for 4-7 min, then incubated at $65^{\circ} \mathrm{C}$ for $60-90 \mathrm{~min}$ in humidity chambers (after Arrighi and Hsu 1974) using 2X SSC. We found it important after each of these steps to briefly rinse the slides for 1-2 min in distilled $\mathrm{H}_{2} \mathrm{O}$ and then allow them to partially air dry for 10-15 min; we also found it useful to prepare (and prewarm) the solutions immediately before use, to keep the $\mathrm{Ba}(\mathrm{OH})_{2}$ solution tightly capped with parafilm (even during slide treatment), to frequently remove the filmy residue (using a tissue) which invariably forms at the surface of a saturated $\mathrm{Ba}(\mathrm{OH})_{2}$ solution, and to rinse the $\mathrm{Ba}(\mathrm{OH})_{2}$-treated slides for $5-10 \mathrm{sec}$ in $0.2 \mathrm{~N} \mathrm{HCl}$ prior to the distilled $\mathrm{H}_{2} \mathrm{O}$ rinse.

Chromosome staining was carried out on fully air dried slides using either Giemsa or the fluorochrome acridine orange (AO). Giemsa staining was for 1015 min using a $5 \%$ solution $(\mathrm{v} / \mathrm{v})$ in $10^{-2} \mathrm{M}$ phosphate buffer at $\mathrm{pH}$ 6.8-7.2. Slides were stained at room temperature, rinsed 1-2 min in distilled $\mathrm{H}_{2} \mathrm{O}$, air-dried, cleared in xylenes for $10 \mathrm{~min}$, and mounted in Permount. AO staining was for $5 \mathrm{~min}$ at room temperature using a $0.1 \%$ solution $(\mathrm{w} / \mathrm{v})$ in $0.1 \mathrm{M} \mathrm{NaCl}$. Slides were stained, washed twice for $30 \mathrm{sec}$ each in $0.1 \mathrm{M} \mathrm{NaCl}$, rinsed $20-30 \mathrm{sec}$ in distilled $\mathrm{H}_{2} \mathrm{O}$, and mounted in $0.1 \mathrm{M} \mathrm{NaCl}$ by sealing the coverslip edges with fingernail polish. We found it important to prepare both the $\mathrm{AO}$ and $\mathrm{NaCl}$ solutions immediately before use. Chromosome preparations stained with Giemsa were photographed in brightfield using technical pan 2415 film at ASA 25-40; those stained with AO were photographed using epifluorescence and panatomic X film at ASA 100-160. Both films were developed in Diafine.

Quantitative determinations of heterochromatin amounts and chromosomal positions were made off positive prints using a digitizer, a small laboratory computer, and a program (BANDSCAN) written by one of us (JRE). The program essentially i) sorts the chromosomes by length, centromere position, and band size and position, ii) arranges the chromosomes into homologous pairs and then the pairs on the basis of chromosome length, and iii) provides both hard copy data and an idealized karyogram of each measured spread. The program is written in BASIC and is available from JRE. 


\section{Results and discussion}

C-banded metaphases stained with AO or Giemsa are shown in Fig. 1; idealized, computer-assisted karyograms averaged from separate measurements of the same and different metaphase spreads from both species are shown in Fig. 2. The latter are particularly impressive and demonstrate the potential use of computer-assisted measurement of fish karyotypes. Some caution, however, is advisable, particularly as regards homologization of chromosomes within or between the species. Several of the chromosomal "pairs" shown in the idealized karyograms are very similar in total length, centromere position, and C-band size and location. As examples, consider the second and third pair in $N$. lutrensis or the third and fourth pair in $N$. venustus. Other examples include pairs five, seven, and nine in $N$. lutrensis, and pairs eight through thirteen in $N$. venustus. In each case, differential chromosome
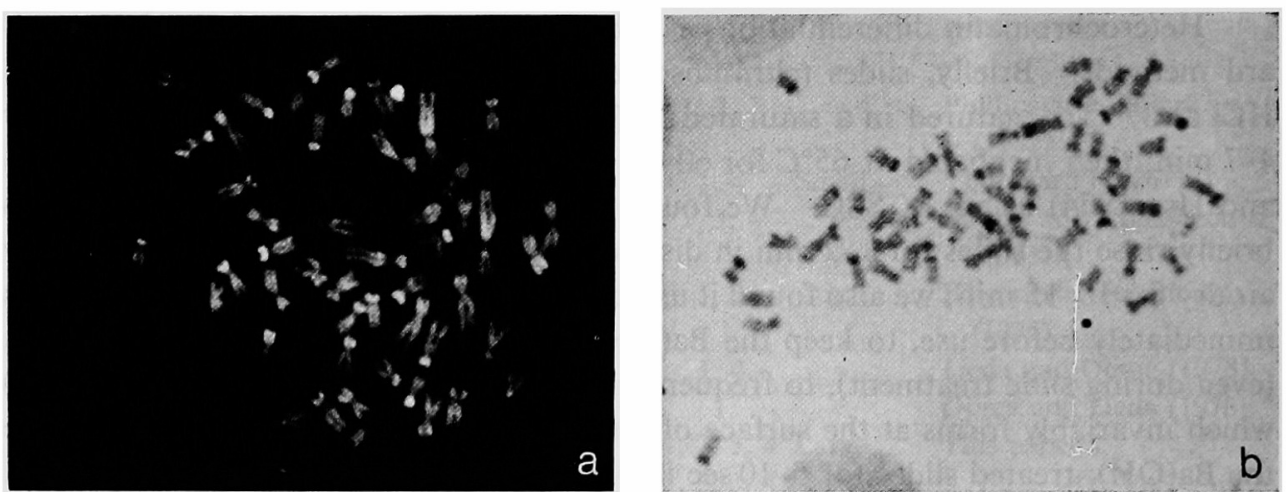

Fig. 1. C-banded metaphases from $N$. lutrensis stained with (a) acridine orange and (b) Giemsa.

contraction during mitosis as well as differential effects of the mitotic inhibitors on chromosome condensation could easily affect both chromosome arm and C-band lengths, and hence render homologization somewhat artificial. Another problem is that both Giemsa and AO are non-specific chromatin or DNA stains and do not differentiate qualitative variation (e.g., AT- or GC- base pair content) in chromosomal heterochromatin. Both problems are aggravated in part by the relatively large amounts of heterochromatin found in the two species (see below). There are, however, more than a few chromosomes whose homologies within species can be inferred from obvious differences in chromosome size, centromere position, or Cbanding. Examples include pairs one, four, and ten in $N$. lutrensis, and pairs one, two, and six in $N$. venustus. Conservatively, we estimate that we can unambiguously differentiate a minimum of nine homologous pairs in $N$. lutrensis and eight in $N$. venustus.

Homologization of chromosomes between (or across) the two species is more difficult. The largest chromosome in both species definitely appears the same by relative size and $\mathrm{C}$-band criteria, and is also known to carry the single nucleolar organizing region (NOR) on the tip of the short arm in both species (Gold 1984). Other putative homologies between the species may include pairs four, twelve, twenty-two, and twenty-five, in $N$. lutrensis with pairs six, fifteen, nineteen, and 
twenty-five, respectively, in $N$. venustus. However, without additional verification using any of the other chromosome banding methods (e.g., G-bands), these homologies are best considered tentative. Alternatively, it is clear from inspection of the karyograms that many chromosomes in both species are very similar in relative size, centomere position, and C-banding. This is especially true for most of the chromosomes with short-arm heterochromatin (see below). On a chromosome by chromosome basis, we estimate minimally that perhaps $60-70 \%$ of the heterochromatin is homologous between the two species by the measurement criteria employed here.

The above notwithstanding, what is striking is the apparent amount and chromosomal distribution of the heterochromatin in both species. Nearly every chromosome, even those with no detectable heterochromatin elsewhere, possessed Cbands at or around the centromere; on some chromosomes (e.g., pairs one-three in both species), the procentric bands extended well beyond the centromeres on one or both arms. Telomeric heterochromatin was relatively sparse and was detected only on the long arm of the largest chromosome pair in both species and on the long arm of one of the smaller submetacentric pairs in N. venustus. Eight pairs of chromosomes in $N$. lutrensis and five pairs in $N$. venustus posessed interstitial C-bands; whereas seventeen pairs of either submetacentric or acrocentric chromosomes in $N$. lutrensis and nineteen pairs in $N$. venustus possessed entirely heterochromatic short
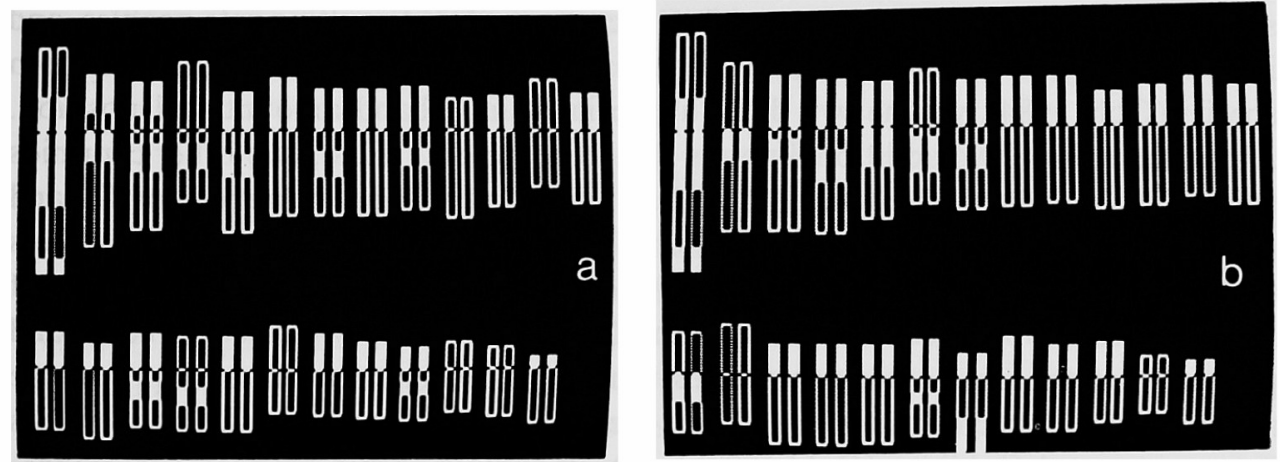

Fig. 2. Computer-assisted C-band karyograms from (a) N. lutrensis and (b) N. venustus.

arms. Such extensive short-arm heterochromatin is of interest in view of our previous findings (Gold et al. 1979, 1981) that almost all of the gross chromosomal variation in North American Cyprinidae involves chromosome arm number differences rather than chromosome number differences. Recent studies in the rodents Peromyscus and Onychomys have shown that most of the remarkable chromosome arm number variation which differentiates species in both genera is due primarily to additions or deletions of short-arm heterochromatin (Robbins and Baker 1981, Baker and Barnett 1981). Very possibly, a similar situation exists in North American Cyprinidae and the karyotype differences thus far observed are due to short-arm heterochromatin variation. Further studies will directly address this issue.

The total amount of heterochromatin in the two species measured as the total length of all heterochromatic regions divided by the total length of all chromosomes was $35 \%$ in $N$. lutrensis and $39 \%$ in $N$. venustus. Comparable quantitative data 
from other fish are not available, but it would appear from visual scrutiny of the published C-band karyotypes (references in Table 1) that the amount of heterochromatin in these two cyprinid species considerably exceeds that found in almost all other fish examined to date. Moreover, since the density-distribution of DNA is probably greater in heterochromatin than in euchromatin (Narayan and Durrant 1983), it is likely that half or more of the total DNA in the two species is localized in chromosomal heterochromatin.

The fact that the genomes of these two cyprinid species contain such an appreciable amount of heterochromatin is of interest to our long term goals of understanding the chromosomal evolution and cytotaxonomy of the group. If nothing else, the extensive heterochromatin content indicates a significant fraction of the cyprinid genome with considerable potential to vary, and which is clearly different in both amount and chromosomal position between the two very closely related species studied here. Thus far, we have examined several different levels of genomic organization in North American cyprinids, including standard karyotypes (Gold et al. 1981), genome sizes (Gold and Price 1985), and AT/GC contents (Karel and Gold unpbl.), and in each case have found that the differences between species were generally insufficient to account for the rapid evolutionary change which characterizes the group. Avise (1977a, b) came to the same conclusion regarding the protein coding gene component. As a specific example, the two species studied here have nearly identical standard karyotypes, genome sizes, AT/GC contents, DNA melting rate profiles, and isozyme/allozyme profiles. The NOR-bearing chromosome is also the same in both species (Gold 1984), yet the two differ appreciably in C-band amount and position. Along these lines, two additional points should be noted. First, two other cyprinids from Asia (Carassius auratus and Cyprinus carpio) have been examined for C-band patterns and in both the amount of heterochromatin detected was considerably less than that exhibited by the two North American forms. Obviously, it will be of future interest to further sample Asian and North American cyprinids. The second point is that the only other fish species thus far discovered to possess appreciable amounts of heterochromatin are from the very chromosomally active families Salmonidae and Gobiidae (Gold 1979b). A close relationship between heterochromatin and classical chromosomal rearrangement (i.e., inversions, translocations, etc.) has been suggested from studies on other animal groups including vertebrates (Hatch et al. 1976, Yoon and Richardson 1978), and indirectly supports the thesis that chromosomal mechanisms may have contributed significantly to the extensive North American cyprinid speciation.

Regarding cytotaxonomy, the C-band data are as yet too few in terms of number of species to allow an accurate assessment of whether the approach will suitably demonstrate phyletic affinities between species. There also is the problem that several chromosomes both within and between the two species are very similar in C-band pattern and hence cannot be unequivocally homologized. However, certain marker chromosomes in North American cyprinids are becoming evident, and in the future it will be informative to compare such chromosomes across species. As one example, the single NOR-bearing chromosomes in both $N$. lutrensis and $N$. venustus appear to be homologous by virtue of similarity in overall size, centromere position, 
NOR-location, and C-banding patterns (Gold 1984, Fig. 3). These two species are thought to be very close relatives in the diverse Notropis subgenus Cyprinella (Gibbs 1957). A third Cyprinella species (Notropis camurus), however, appears to possess a different NOR-bearing chromosome (Amemiya and Gold unpbl.) which is in accord with the present classification of the species since $N$. camurus is thought to be a distant relative of the other two (Gibbs 1957, 1961). Given the general difficulty in working with fish chromosomes, however, it is probable that most fish cytotaxonomy will initially have to be practiced on a chromosome by chromosome basis.

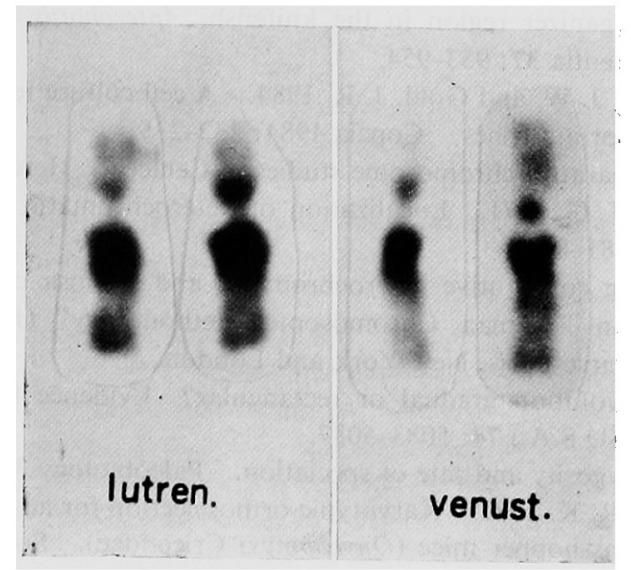

Fig. 3. C-bands with Giemsa on the NOR chromosome pair of $N$. lutrensis and N. venustus.

\section{Summary}

Chromosomal heterochromatin was differentiated in two closely related species of the North American cyprinid genus Notropis. The amounts of heterochromatin in the genomes of the two species were appreciable: $35 \%$ in $N$. lutrensis and $39 \%$ in $N$. venustus. The chromosomal distribution of heterochromatin was similar in both species: most or all chromosomes contained procentric bands, a few possessed terminal and/or interstitial bands, and there was a preponderance of submetacentric and acrocentric chromosomes with entirely heterochromatic short arms. Several chromosomes could be putatively homologized either within or between the two species, although in general the amount and type of heterochromatin made precise homologization difficult. The total amount of heterochromatin resolved in these two species is considerably more than that found among most of the relatively few fish species studied to date. Heterochromatin appears to be one of the few potentially variable fractions of the cyprinid genome which may have contributed to the extensive speciation exhibited by these fish in North America. A few marker chromosomes, specifically the one bearing the nucleolus organizer region or NOR, may prove valuable in cyprinid taxonomy. 
Experiment Station and by NSF Grant BSR-8415428. We thank Michael Ellison for help in collecting specimens.

\section{References}

Abe, S. and Muramoto, J. 1974. Differential staining of chromosomes of two salmonoid species, Salvelinus leucomaenis (Pallas) and Salvelinus malma (Walbaum). Proc. Jpn. Acad. 50: 507-511.

Almeida Toledo, L. F., Foresti, F. and Almeida Toledo, S. 1981. Constitutive heterochromatin and nucleolus organizer region in the knifefish, Apteronotus albifrons (Pisces, Apteronotidae). Experientia 37: 953-954.

Amemiya, C. T., Bickham, J. W. and Gold, J. R. 1984. A cell culture technique for chromosome preparation in cyprinid fishes. Copeia 1984: 232-235.

Árnason, U. 1974. Comparative chromosome studies in Cetacea. Hereditas 77: 1-36.

Arrighi, F. E. and Hsu, T. C. 1971. Localization of heterochromatin in human chromosomes. Cytogenetics 10: 81-86.

- and - 1974. Staining constitutive heterochromatin and Giemsa crossbands of mammalian chromosomes. In "Human Chromosome Methodology" (J. J. Yunis, ed.). Chapter 8: 59-71. Academic Press, New York and London.

Avise, J. C. 1977a. Is evolution gradual or rectangular? Evidence from living fishes. Proc. Natl. Acad. Sci. (U.S.A.) 74: 5083-5087.

- 1977b. Genic heterozygosity and rate of speciation. Paleobiology 3: 422-432.

Baker, R. J. and Barnett, R. K. 1981. Karyotypic orthoselection for additions of heterochromatic short arms in grasshopper mice (Onychomys: Cricetidae). Southwestern Nat. 26: 125131.

Baverstock, P. R., Gelder, M. and Jahnke, A. 1982. Cytogenetic studies of the Australian rodent Uromys caudimaculatus, a species showing extensive heterochromatin variation. Chromosoma 84: 517-533.

Fry, K. and Salser, W. 1977. Nucleotide sequences of HS- $\alpha$ satellite DNA from kangaroo rat Dipodomys ordii and characterization of similar sequences in other rodents. Cell 12: 1069-1084.

Gibbs, R. H., Jr. 1957. Cyprinid fishes of the subgenus Cyprinella of Notropis I. Systematic status of the subgenus Cyprinella, with a key to the species exclusive of the lutrensis-ornatus complex. Copeia 1957: 185-195.

- 1961. Cyprinid fishes of the subgenus Cyprinella of Notropis IV. The Notropis galacturuscamurus complex. Amer. Midl. Nat. 66: 337-354.

Gold, J. R. 1979a. Cytogenetics. In "Fish Physiology" (W. S. Hoar, D. J. Randall and J. R. Brett, eds.). Volume VIII: 353-405. Academic Press, New York and London.

- 1979b. Chromosomal change and evolution in North American fishes. American Society of Ichthyologists and Herpetologists, Orono, Maine.

- 1980. Chromosomal change and rectangular evolution in North American cyprinid fish. Genet. Res. 35: 157-164.

- 1984. Silver-staining and heteromorphism of chromosomal nucleolus organizer regions in North American cyprinid fishes. Copeia 1984: 133-139.

- and Price, H. J. 1985. Genome size variation among North American minnows (Cyprinidae) I. Distribution of the variation in five species. Heredity 54: 297-305.

-, Whitlock, C. W., Karel, W. J. and Barlow, J. A. 1979. Cytogenetic studies in North American minnows (Cyprinidae) VI. Karyotypes of thirteen species in the genus Notropis. Cytologia 44: 457-466.

-, Womac, W. D., Deal, F. H. and Barlow, J. A. 1978. Gross karyotypic change and evolution in North American cyprinid fishes. Genet. Res. 32: 37-46.

-, - , - and - 1981. Cytogenetic studies in North American minnows (Cyprinidae) VII. Karyotypes of thirteen species from the southern United States. Cytologia 46: 105-115. 
Gregory, P. E., Howard-Peebles, P. N., Ellender, R. D. and Martin, B. J. 1980. C-banding of chromosomes from three established marine fish cell lines. Copeia 1980: 545-547.

Haaf, T. and Schmid, M. 1984. An early stage of $\mathrm{ZW} / \mathrm{ZZ}$ sex chromosome differentiation in Poecilia sphenops var. melanistica (Poeciliidae, Cyprinodontiformes). Chromosoma 89: $37-41$.

Haiduk, M. W., Baker, R. J., Robbins, L. W. and Schlitter, D. A. 1981. Chromosomal evolution in African Megachiroptera: G- and C- band assessment of the magnitude of change in similar standard karyotypes. Cytogenet. Cell Genet. 29: 221-232.

Hatch, F. T., Bodner, A. J., Mazrimas, J. A. and Moore, D. H. 1976. Satellite DNA and cytogenetic evolution. Chromosoma 58: 155-168.

John, B. and Miklos, G. L. G. 1979. Functional aspects of satellite DNA. Int. Rev. Cytol. 58: $1-114$.

Kligerman, A. D. and Bloom, S. E. 1977. Distribution of F-bodies, heterochromatin, and nucleolar organizers in the genome of the central mudminnow, Umbra limi. Cytogenet. Cell Genet. 18: 182-196.

Kornfield, I. 1981. Distribution of constitutive heterochromatin and the evolution of sex chromosomes in Fundulus. Copeia 1981: 916-918.

-, Ritte, U., Richler, C. and Wahrman, J. 1979. Biochemical and cytological differentiation among cichlid fishes of the Sea of Galilee. Evolution 33: 1-14.

Lee, M. R. and Elder, F. F. B. 1980. Yeast stimulation of bone marrow mitosis for cytogenetic investigations. Cytogenet. Cell Genet. 26: 36-40.

Mascarello, J. T. and Mazrimas, J. A. 1977. Chromosomes of antelope squirrels (genus Ammospermophilus): a systematic banding analysis of four species with unusual constitutive heterochromatin. Chromosoma 64: 207-217.

Mengden, G. A. 1981. Linear differentiation of the C-band pattern of the $\mathrm{W}$ chromosome in snakes and birds. Chromosoma 83: 275-287.

Narayan, R. K. J. and Durrant, A. 1983. DNA distribution in chromosomes of Lathyrus species. Genetica 61: 47-53.

Ojima, Y. and Ueda, T. 1978. New C-banded marker chromosomes found in carp-funa hybrids. Proc. Jpn. Acad. 54, Ser. B: 15-20.

Park, E.-H. and Grimm, H. 1981. Distribution of C-band heterochromatin in the ZW sex chromosomes of European and American eels (Anguillidae, Teleostomi). Cytogenet. Cell Genet. 31: 167-174.

Pathak, S. and Wurster-Hill, D. H. 1977. Distribution of constitutive heterochromatin in carnivores. Cytogenet. Cell Genet. 18: 245-254.

Patton, J. L. and Sherwood, S. W. 1982. Genome evolution in pocket gophers (genus Thomomys) I. Heterochromatin variation and speciation potential. Chromosoma 85: 149-162.

Phillips, R. B. and Zajicek, K. D. 1982. Q band chromosomal polymorphisms in lake trout (Salvelinus namaycush). Genetics 101: 227-234.

Robbins, L. W. and Baker, R. J. 1981. An assessment of the nature of chromosomal rearrangements in 18 species of Peromyscus (Rodentia: Cricetidae). Cytogenet. Cell Genet. 31: 194-202.

Schmid, M. 1978a. Chromosome banding in Amphibia I. Constitutive heterochromatin and nucleolus organizer regions in Bufo and Hyla. Chromosoma 66: 361-388.

- 1978b. Chromosome banding in Amphibia II. Constitutive heterochromatin and nucleolus organizer regions in Ranidae, Microhylidae and Rhacophoridae. Chromosoma 68: 131-148.

Thode, G., Cano, J. and Alvarez, M. C. 1983. Association of nucleolus organizer chromosomes shown by silver staining in Gobius fallax. J. Hered. 74: 480-482.

Thorgaard, G. H. 1976. Robertsonian polymorphism and constitutive heterochromatin distribution in chromosomes of the rainbow trout (Salmo gairdneri). Cytogenet. Cell Genet, 17: 174-184.

Ueda, T. and Ojima, Y. 1978. Differential chromosomal characteristics in the funa subspecies (Carassius). Proc. Jpn. Acad. 54, Ser. B: 283-288. 
- and - 1983. Karyotypes with C-banding patterns of two species in the genus Salvelinus of the family Salmonidae. Proc. Jpn. Acad. 59, Ser. B: 343-346.

Uwa, H. and Ojima, Y. 1981. Detailed and banding karyotype analyses of the medaka, Oryzias latipes, in cultured cells. Proc. Jpn. Acad. 57, Ser. B: 39-43.

-, Iwamatsu, T. and Ojima, Y. 1981. Karyotype and banding analyses of Oryzias celebensis (Oryziatidae, Pisces) in cultured cells. Proc. Jpn. Acad. 57, Ser. B: 95-99.

-, Tanaka, K. and Formacion, M. J. 1982. Karyotype and banding analyses of the Hainan medaka, Oryzias curvinotus. Chrom. Inform. Serv, 33: 15-17.

Wiberg, U. H. 1983. Sex determination in the European eel (Anguilla anguilla, L.). Cytogenet. Cell Genet. 36: 589-598.

Yoon, J.S. and Richardson, R. H. 1978. A mechanism of chromosomal rearrangements: the role of heterochromatin and ectopic joining. Genetics 88: 305-316.

Yosida, T. H. 1975. Diminution of heterochromatic C-bands in relation to the differentiation of Rattus species. Proc. Jpn. Acad. 51: 659-663.

Yunis, J. J. and Yasmineh, W. G. 1971. Heterochromatin, satellite DNA, and cell function. Science 174: 1200-1209.

-, Roldan, L., Yasmineh, W. G. and Lee, J. C. 1971. Staining of satellite DNA in metaphase chromosomes. Nature 231: 532-533.

Zenzes, M. T. and Voiculescu, I. 1975. C-banding patterns in Salmo trutta, a species of tetraploid origin. Genetica 45: 531-536. 